\title{
ORGANOMETALLIC $\left[\mathrm{Fe}_{3} \mathrm{O}\left(\mathrm{OOCC}_{6} \mathrm{H}_{5}\right)_{6}\left(\mathrm{H}_{2} \mathrm{O}\right)_{3}\right]\left(\mathrm{NO}_{3}\right)$ AS INTERCALANT OF BENTONITE
}

\author{
Hasja Paluta Utami ${ }^{1, *}$ and Donny Marihot Siburian ${ }^{1}$ \\ ${ }^{1}$ Departement of Chemistry, Faculty of Mathematic and Natural Sciences, Sriwijaya University \\ *Corresponding Author e-mail : hasjapaluta8@gmail.com
}

\begin{abstract}
Intercalation of organometalic compounds $\left[\mathrm{Fe}_{3} \mathrm{O}\left(\mathrm{OOCC}_{6} \mathrm{H}_{5}\right)_{6}\left(\mathrm{H}_{2} \mathrm{O}\right)\right]\left(\mathrm{NO}_{3}\right) \cdot \mathrm{nH}_{2} \mathrm{O}$ on bentonite by weight ratio of bentonite:organometallic (1:1); (1:2); (1:3); and (1:4) has been carried out. The intercalation bentonite was characterized using FT-IR spectrophotometer, XRD and XRF anayses. Characterization using FT-IR spectrophotometer showed higher intensity of peak wavenumber at $470.6 \mathrm{~cm}^{-1}$ for $\mathrm{Fe}_{3}-\mathrm{O}$ vibration on the ratio $(1: 3)$. While XRD characterization showed the shift of diffraction angle of $2 \theta$ was $5.2^{\circ}$ and has bacal spacing of $16.8 \AA$. In the XRF characterization, the intercalation process of organometalic compounds $\left[\mathrm{Fe}_{3} \mathrm{O}\left(\mathrm{OOCC}_{6} \mathrm{H}_{5}\right)_{6}\left(\mathrm{H}_{2} \mathrm{O}\right)\right]\left(\mathrm{NO}_{3}\right) \cdot \mathrm{nH}_{2} \mathrm{O}$ on bentonite was occurred optimally with percentage of metal oxide reached $71.75 \%$.
\end{abstract}

Keywords: intercalation, bentonite, organometallic, $\left[\mathrm{Fe}_{3} \mathrm{O}\left(\mathrm{OOCC}_{6} \mathrm{H}_{5}\right)_{6}\left(\mathrm{H}_{2} \mathrm{O}\right)\right]\left(\mathrm{NO}_{3}\right) \cdot \mathrm{nH}_{2} \mathrm{O}$.

\section{INTRODUCTION}

Bentonite is a layered material contain inorganic minerals who can find easily in natural (Abderrazek et al, 2016). Bentonite are used as adsorbent, catalyst, ion exchange, and various industrial applications (Santos et al, 2016). In the application of bentonite as adsorben have some weakness, due to impurities of some minerals that can make the adsorption is not optimal. Therefore, to optimize the adsorption process then bentonite should be activated. The procces activation of bentonite is intended to separate the impurities naturally from bentonite. In general, there are two step of activation procces for activation including physically and chemically processes. On physical processes is needed to combution in a high temperature causes water moleculs from crystal and other inorganic constituents, so that two cluster $\mathrm{OH}$ who bondered each other, they have to detach one water molecul (Scoonheydt et al, 2008), while on chemical processes by using acid mineral such as sulfuric acid is intended to omit the metals that be found in bentonite and banded in ion $\mathrm{H}^{+}$which is originated from acid. therefore the layer who as an insertion entry will be larger. The modification of bentonite is expected to produce bentonite which can be conducted by insertion of molecules, compounds, and organic/inorganic complexes.

The research of layer materials intercalation including bentonite using metal oxides shows distance between layer is a litlle small (Yang et al, 2005). Thus higher compound with positive charge is needed as intercalant of bentonite. This research was conducted an intercalation process of bentonite using a organometalic compund as insertion. Organometalic compound $\left[\mathrm{Fe}_{3} \mathrm{O}\left(\mathrm{OOCC}_{6} \mathrm{H}_{5}\right)_{6}\left(\mathrm{H}_{2} \mathrm{O}\right)\right]\left(\mathrm{NO}_{3}\right) \cdot \mathrm{nH}_{2} \mathrm{O}$ have advantage such as high reactivity, high cation size, and also easy to synthesis. In this research, various weight of organometallic compond has been used to know the optimal intercalation process. The ratio of bentonite:organometallic complex was

\section{Article History}

Submitted: 23 July 2016

Accepted: 5 August 2016

DOI: 10.26554/sti.2016.1.1.20-24
(1:1); (1:2); (1:3); and (1:4). Product of insertion was characterized by spectrofotometer FT-IR, XRD, and XRF analyses in order to know the optimal insertion process.

\section{EXPERIMENTAL SECTION}

\section{Materials}

Natural bentonite was obtained from Jambi Province, Indonesia. Sulfuric acid, Iron(III) nitrate, sodium benzoate, and sodium hydroxide was obtained from Merck and directly used after purchased. Deionized water was supplied from Purite ${ }^{\circledR}$.

\section{Preparation of Bentonite (Ozcan, 2016)}

The nature bentonite is prepared by physically and chemically proceses. $100 \mathrm{~g}$ of natural bentonite was heated using furnace at $400{ }^{\circ} \mathrm{C}$ for two hours then the material was kept at room temperature over night. The bentonite then was acidified using sulfuric acid for two hours. Bentonite after treatment was characterized using FT-IR spectrophotometer, XRD, and XRF.

\section{Synthesis of Organometalic Compunds $\left[\mathrm{Fe}_{3} \mathrm{O}\left(\mathrm{OOCC}_{6} \mathrm{H}_{5}\right)_{6}\left(\mathrm{H}_{2} \mathrm{O}\right)\right]\left(\mathrm{NO}_{3}\right) \cdot \mathrm{nH}_{2} \mathrm{O}$ (Uchida et al, 2008)}

Synthesis of organometallic compounds was carried out by mixing a $32 \mathrm{~g}$ of iron(III)nitrate that has been dissolved in 100 $\mathrm{mL}$ of water. In the solution was added $24 \mathrm{~g}$ sodium benzoate and the mixtures were stirred by magnetic stirrer for 15 minutes. The brown orange solution will be formed, filtered, washed by water to obtain $\left[\mathrm{Fe}_{3} \mathrm{O}\left(\mathrm{OOCC}_{6} \mathrm{H}_{5}\right)_{6}\left(\mathrm{H}_{2} \mathrm{O}\right)\right]\left(\mathrm{NO}_{3}\right) \cdot \mathrm{nH}_{2} \mathrm{O}$. Organometallic compound was characterized using FT-IR spectrophotometer.

\section{Intercalation of Bentonite with Organometalic Compound $\left[\mathrm{Fe}_{3} \mathrm{O}\left(\mathrm{OOCC}_{6} \mathrm{H}_{5}\right)_{6}\left(\mathrm{H}_{2} \mathrm{O}\right)\right]\left(\mathrm{NO}_{3}\right) \cdot \mathrm{nH}_{2} \mathrm{O}$ (Gil et al, 2009)}

Bentonite was mixed with $200 \mathrm{~mL}$ water to form white suspension (reactan A). Organometallic compound as intercalant compound was prepared by adding $100 \mathrm{~mL}$ sodium hydroxide $(\mathrm{NaOH}) 1 \mathrm{M}$ into $15 \mathrm{~g}$ of organometallic compound (reactan B). Reactan A and B was mixed and the mixtures was 
refluxed with gentle stirring for 24 hours at room temperature under nitrogen gas. The product intercalation of bentonite with organometallic compounds was washed with water and dried at $90{ }^{\circ} \mathrm{C}$. In order to know the optimum intercalation process, the ratio of bentonite:organometallic compound was applied (1:1); $(1: 2) ;(1: 3)$; and (1: 4). The bentonite intercalated organometallic compounds were characterized using FT-IR spectrophotometer, XRD and XRF analysis.

\section{RESULTS AND DISCUSSION}

\section{Synthesis and Characterization of Organometallic Compounds $\left[\mathrm{Fe}_{3} \mathrm{O}\left(\mathrm{OOCC}_{6} \mathrm{H}_{5}\right)_{6}\left(\mathrm{H}_{2} \mathrm{O}\right)_{3}\right]\left(\mathrm{NO}_{3}\right) \cdot \mathrm{nH}_{2} \mathrm{O}$}

Synthesis of organometallic compounds $\left[\mathrm{Fe}_{3} \mathrm{O}\left(\mathrm{OOCC}_{6} \mathrm{H}_{5}\right)_{6}\right.$ $\left.\left(\mathrm{H}_{2} \mathrm{O}\right)_{3}\right]\left(\mathrm{NO}_{3}\right) \cdot \mathrm{nH}_{2} \mathrm{O}$ was carried out under air conditions without protection of an inert gas, which has different from almost synthesis of organometallic complexes (Szafran et al, 1991). Organometallic compounds $\left[\mathrm{Fe}_{3} \mathrm{O}\left(\mathrm{OOCC}_{6} \mathrm{H}_{5}\right)_{6}\right.$ $\left.\left(\mathrm{H}_{2} \mathrm{O}\right)_{3}\right]\left(\mathrm{NO}_{3}\right) \cdot \mathrm{nH}_{2} \mathrm{O}$ has light brown crystals. The organometallic compounds were then characterized using FTIR spectrosphotometer aimed to identifying functional groups showed in Figure 1.

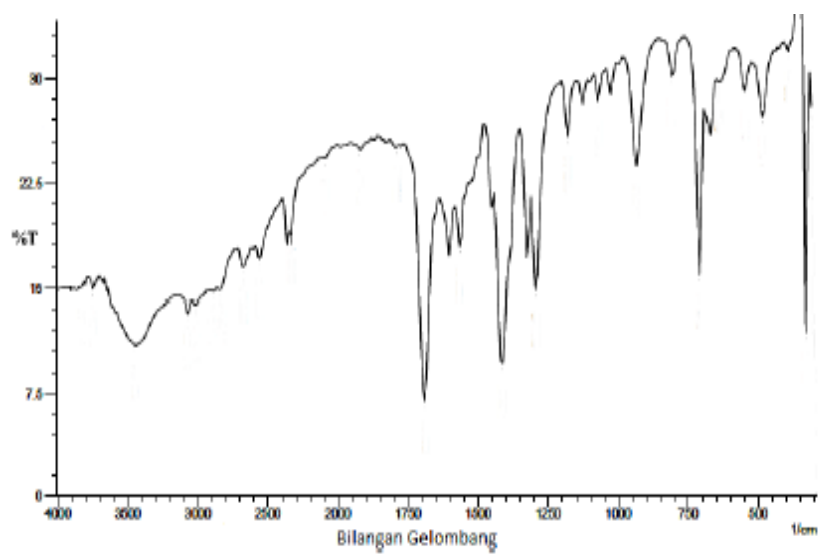

Figure 1. FT-IR Spectrum of Organometallic Compounds $\left[\mathrm{Fe}_{3} \mathrm{O}\left(\mathrm{OOCC}_{6} \mathrm{H}_{5}\right)_{6}\left(\mathrm{H}_{2} \mathrm{O}\right)_{3}\right]\left(\mathrm{NO}_{3}\right) \cdot \mathrm{nH}_{2} \mathrm{O}$

Table 1. Wavenumbers data of organometallic compounds $\left[\mathrm{Fe}_{3} \mathrm{O}\left(\mathrm{OOCC}_{6} \mathrm{H}_{5}\right)_{6}\left(\mathrm{H}_{2} \mathrm{O}\right)_{3}\right]\left(\mathrm{NO}_{3}\right) \cdot \mathrm{nH}_{2} \mathrm{O}$

\begin{tabular}{ll}
\hline Wavenumber $\left(\mathrm{cm}^{-1}\right)$ & Functional groups \\
\hline 3410.1 & $\mathrm{v}(\mathrm{O}-\mathrm{H})$ \\
3070.6 & $\mathrm{v}(\mathrm{Ar}-\mathrm{H})$ \\
$1419.6-1612.4$ & $\mathrm{v}(\mathrm{C}-\mathrm{H}), \mathrm{v}(\mathrm{C}-\mathrm{O}),(\mathrm{C}-$ \\
& $\mathrm{C})$ \\
709.8 & $\mathrm{v}(\mathrm{N}-\mathrm{O})$ \\
469.0 & $v(\mathrm{Fe}-\mathrm{O})$ \\
\hline
\end{tabular}

Figure 1. shows the peaks of functional groups of organometallic compounds appearing at wavenumbers 400 $4000 \mathrm{~cm}^{-1}$. The main peaks of the organometallic compound appear at the $469 \mathrm{~cm}^{-1}$ for $\mathrm{Fe}-\mathrm{O}$ vibration (Hasegawa et al, 2007). At the wavenumber $709.8 \mathrm{~cm}^{-1}$ for the $\mathrm{N}-\mathrm{O}$ vibration as the counter ion of the benzoate ligand. $\left[\mathrm{Fe}_{3} \mathrm{O}\left(\mathrm{OOCC}_{6} \mathrm{H}_{5}\right)_{6}\right.$ $\left.\left(\mathrm{H}_{2} \mathrm{O}\right)_{3}\right]\left(\mathrm{NO}_{3}\right) \cdot \mathrm{nH}_{2} \mathrm{O}$ has a $\mathrm{C}-\mathrm{H}$ vibration, the $\mathrm{C}-\mathrm{O}$ vibration, and the $\mathrm{C}-\mathrm{H}$ vibration, which appears at the wavenumbers $1419.6 \mathrm{~cm}^{-1}, 1612.4 \mathrm{~cm}^{-1}$ (Lesbani et al, 2008). Wavenumber $3070.6 \mathrm{~cm}^{-1}$ is indicated for $\mathrm{Ar}-\mathrm{H}$ bend vibration. The absorption band at $1689.6 \mathrm{~cm}^{-1}$ for $\mathrm{O}-\mathrm{H}$ vibration indicating the presence of water ligands in organometallic compounds, which has also strongly appeared by vibration at $3410.1 \mathrm{~cm}^{-1}$. The data of wavenumbers of organometallic compounds $\left[\mathrm{Fe}_{3} \mathrm{O}\left(\mathrm{OOCC}_{6} \mathrm{H}_{5}\right)_{6}\left(\mathrm{H}_{2} \mathrm{O}\right)_{3}\right]\left(\mathrm{NO}_{3}\right) \cdot \mathrm{nH}_{2} \mathrm{O}$ are summarized in Table 1.

\section{Identification of Natural Bentonite and Bentonite Intercalated Organometallic Compounds $\left[\mathrm{Fe}_{3} \mathrm{O}\left(\mathrm{OOCC}_{6} \mathrm{H}_{5}\right)_{6}\left(\mathrm{H}_{2} \mathrm{O}\right)_{3}\right]\left(\mathrm{NO}_{3}\right) \cdot \mathrm{nH}_{2} \mathrm{O}$ using FT-IR Spectrophotometer}

Before the intercalation process, natural bentonite was characterized using FT-IR spectrophotometer aimed at identifying functional groups. FT-IR spectra of natural bentonite at Figure 2(A) shows vibration of $\mathrm{Al}-\mathrm{OH}-\mathrm{Al}$ vibration in wavenumber $3626.1 \mathrm{~cm}^{-1}$ and vibration of $\mathrm{Al}-\mathrm{OH}-\mathrm{Al}$ at wavenumber $910.4 \mathrm{~cm}^{-1}$. The water content that acts as an interlayer molecule on bentonite appears as a strech vibration of $\mathrm{H}-\mathrm{O}-\mathrm{H}$ observed at the wavenumber $3448.7 \mathrm{~cm}^{-1}$ while the $\mathrm{H}$ $\mathrm{O}-\mathrm{H}$ bend vibration appears at $1635.6 \mathrm{~cm}^{-1}$. The absorption at $1033.8 \mathrm{~cm}^{-1}$ indicate the bend vibration of Si-O-Si (Derrick et al, 1999).

There are two stages to remove impurities on bentonite i.e. heating at $400^{\circ} \mathrm{C}$ and acidification using sulfuric acid $\left(\mathrm{H}_{2} \mathrm{SO}_{4}\right)$. On bentonite with heating at $400^{\circ} \mathrm{C}$ causes a change in deformation of the $\mathrm{H}_{2} \mathrm{O}$ bond, since the existing $\mathrm{H}_{2} \mathrm{O}$ is released, therefore the bentonite peak becomes widened and expanded so that it eventually collapses at $400^{\circ} \mathrm{C}$. The success of this process are characterized by changes in functional groups with the shift in the wavenumbers as seen in Figure 2 (B). The absorption bands in Figure 2 (B) of the $\mathrm{Al}-\mathrm{OH}-\mathrm{Al}$ vibration are shifted at $3695.6 \mathrm{~cm}^{-1}$ and quartz minerals are shifted at 694.3 $\mathrm{cm}^{-1}$ wavenumbers. Vibration of stretch and bend of $\mathrm{H}-\mathrm{O}-\mathrm{H}$ appear on the same wavenumber in natural bentonite, ie at $3448.7 \mathrm{~cm}^{-1}$ and at $1635.6 \mathrm{~cm}^{-1}$. The stretching and bending vibration of Si-O-Si are shown in the $1033.8 \mathrm{~cm}^{-1}$ and $532 \mathrm{~cm}^{-1}$ and the Al-OH-Al bending vibrations remain at the $910.4 \mathrm{~cm}^{-1}$. The second activation process of natural bentonite is acidification using sulfuric acid. Acidification using sulfuric acid aims to remove small metals as impurities attached to bentonite. This activation will open interlayer of bentonite. FT-IR spectrum in Figure 2 (C) shows the shift of wavenumbers of bentonite after acid activation. The absorption band for $\mathrm{Al}-\mathrm{OH}-$ $\mathrm{Al}$ stretching vibration shifts to wavenumber $3672.4 \mathrm{~cm}^{-1}$. The $\mathrm{H}-\mathrm{O}-\mathrm{H}$ stretching vibration shifts to wavenumber $3425.5 \mathrm{~cm}^{-1}$ and the Si-O-Si stretching vibration stay at the wavenumber $1041.5 \mathrm{~cm}^{-1}$. The bending vibrations of $\mathrm{Al}-\mathrm{OH}-\mathrm{Al}$ appearing at $910.4 \mathrm{~cm}^{-1}$ and the $\mathrm{H}-\mathrm{O}-\mathrm{H}$ bending vibrations appear at 1635.6 $\mathrm{cm}^{-1}$. Similar to natural bentonite and bentonite heating at $400^{\circ} \mathrm{C}$ there is no shift in wavenumbers, stretching and bending vibrations of Si-O-Si stay at wavenumber $532 \mathrm{~cm}^{-1}$.

Intercalation process of bentonite with organometallic compound was completely conducted by adding water to bentonite which is continued with addition of sodium oxide $(\mathrm{NaOH})$. This goal is to build a suspension for easy intercalation process. In the process of intercalation, there is no contact of oxygen form the air, which has protected by introducing $\mathrm{N}_{2}$ gas. The process of intercalation of bentonite with these 
organometallic compounds is carried out by varying the weight ratio, between the weight of the bentonite and the organometallic weight : (1:1), (1:2), (1:3) and (1:4). This experiment was carried out in order to know the optimum intercalation process.

The results of intercalation of organometallic compounds with the weight ratio of (1: 1), (1:2), (1:3) and (1:4) were characterized using FT-IR spectrophotometer to see functional groups formed as in Figure 3. In Figure 3 (D), it is seen that the vibration of the $\mathrm{Fe}-\mathrm{O}$ organometallic compound appears at a wavenumber of $462.5 \mathrm{~cm}^{-1}$. The strong of absorption bands for $\mathrm{Al}-\mathrm{OH}-\mathrm{Al}$ stretch vibrations shifted to $3618.4 \mathrm{~cm}^{-1}$. The $\mathrm{O}-\mathrm{H}$ stretching vibration widened at $3448.7 \mathrm{~cm}^{-1}$. This indicates the presence of an $\mathrm{O}-\mathrm{H}$ group on benzoate as well as a benzoate ligand in the form of $\mathrm{C}-\mathrm{C}$ vibration, $\mathrm{C}=\mathrm{C}$ vibration, $\mathrm{C}=\mathrm{O}$ vibration appearing at wavenumbers $1388.7-1635 \mathrm{~cm}^{-1}$. Si-O-Si stretch vibration at wavenumber $1018.4 \mathrm{~cm}^{-1}$ and $\mathrm{Al}-\mathrm{OH}-\mathrm{Al}$ bending vibrations that appear on wavenumbers 910.4. Stretching and bending vibrations of Al-O-Si are seen at 524.6 $\mathrm{cm}^{-1}$.

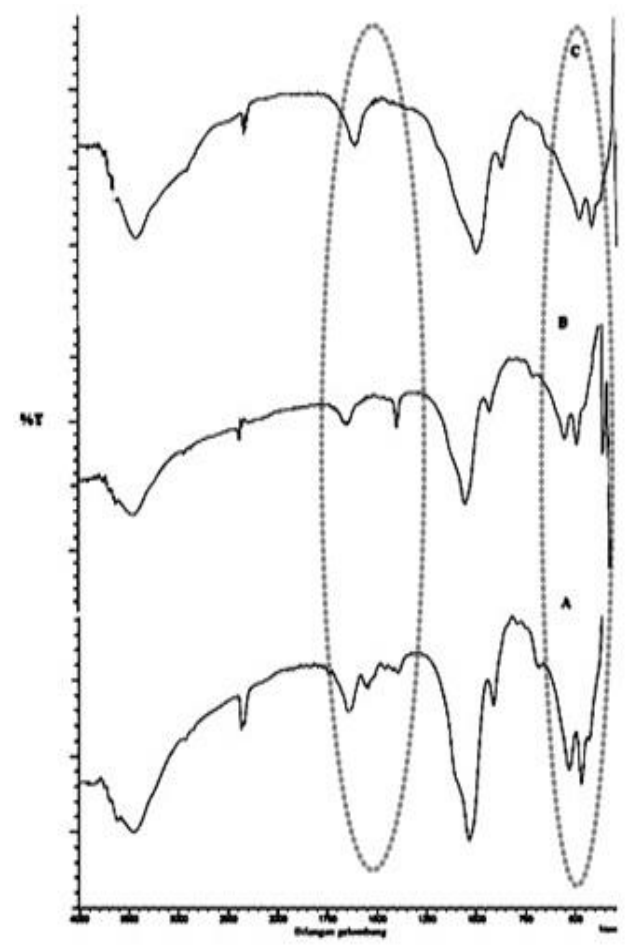

Figure 2. FT-IR spectrum of A)

natural bentonite. B) bentonite with heating at $400{ }^{\circ} \mathrm{C}$ C) bentonite with acidification

In the result of bentonite intercalation of organometamic compound in Figure $3(\mathrm{E})(1: 2)$ it is seen that the vibration of $\mathrm{Fe}-\mathrm{O}$ organometallic compound appears at wavenumber 470.6 $\mathrm{cm}^{-1}$. The emergence of absorbing bands for the vibration of the $\mathrm{Al}-\mathrm{OH}-\mathrm{Al}$ strain shifted at the wavenumber $3618.4 \mathrm{~cm}^{-1}$. The $\mathrm{OH}$ vibration widened at $3448.7 \mathrm{~cm}^{-1}$, the vibration of the $\mathrm{C}-\mathrm{C}$, the vibration of $\mathrm{C}=\mathrm{C}$, the vibration $\mathrm{C}=\mathrm{O}$ at $1388.7-1635 \mathrm{~cm}^{-}$ 1 and vibration of Si-O-Si strain at $1033.8 \mathrm{~cm}^{-1}$. Al-OH-Al buckling vibrations that appear at the $910.4 \mathrm{~cm}^{-1}$. Strecthing and bending vibrations of $\mathrm{Al}-\mathrm{O}-\mathrm{Si}$ are appeared at $532.3 \mathrm{~cm}^{-1}$
In the result of bentonite intercalation of organometallic compound Figure 3 (F) (1:3) it is appeared that the emergence of strong absorption at wavenumber $470,6 \mathrm{~cm}^{-1}$ for vibration of $\mathrm{Fe}-\mathrm{O}$ organometallic compound. The presence of absorbing bands for the $\mathrm{OH}$ vibration is widened in the wavenumber $3448.7 \mathrm{~cm}^{-1}$. The vibration of the $\mathrm{C}-\mathrm{C}$, the vibration of $\mathrm{C}=\mathrm{C}$, the vibration $\mathrm{C}=\mathrm{O}$ occurs at the wavenumbers $1388.7-1635$ $\mathrm{cm}^{-1}$, Si-O-Si at $1033.8 \mathrm{~cm}^{-1}$. Al-OH-Al buckling vibrations that appear at $910.4 \mathrm{~cm}^{-1}$ wavenumbers, whereas, stretching vibration of $\mathrm{Al}-\mathrm{O}-\mathrm{Si}$ bends are appeared at $524.6 \mathrm{~cm}^{-1}$. These vibrations are almost similar with vibration in Figure $3 \mathrm{G}$.

The FT-IR spectra of Figure 3 show that the variation in the weight ratio of intercalated bentonite did not differ significantly. In order to know the optimal intercalation process, characterization using XRD was conducted for further analysis.

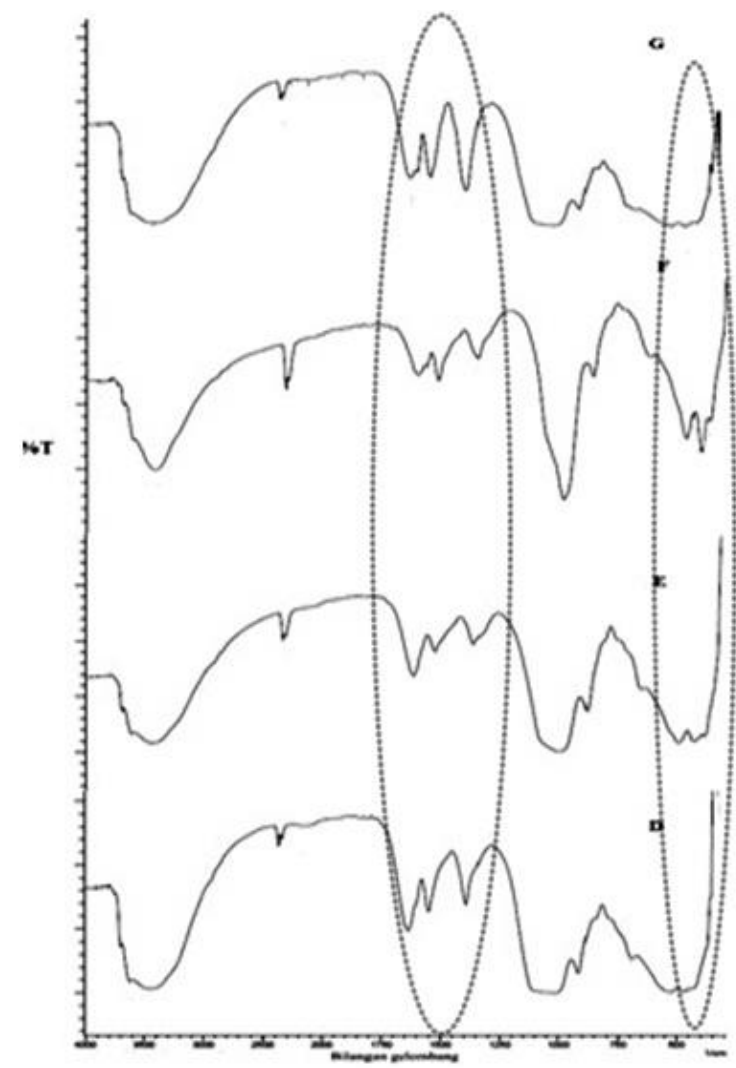

Figure 3. FT-IR spectrum of Intecalated Bentonite, D) 1:1, E) $1: 2$, F) 1:3, G) 1:4.

\section{Identification of Natural Bentonite and Bentonite Intercalated Organometallic Compounds $\left[\mathrm{Fe}_{3} \mathrm{O}\left(\mathrm{OOCC}_{6} \mathrm{H}_{5}\right)_{6}\left(\mathrm{H}_{2} \mathrm{O}\right)_{3}\right]\left(\mathrm{NO}_{3}\right) \cdot \mathrm{nH}_{2} \mathrm{O}$ using X-Ray Diffraction}

The objectives analysis using XRD is to look at the structural changes that occur in bentonite after intercalation by observing the diffraction angle change $(2 \theta)$. Bentonite is a class of minerals that contain montmorillonite as main fraction. (Brindley et al, $1990)$. Bentonite shows the observed montmorillonite at $2 \theta$ from $3-6^{\circ}$. This is evident from the diffraction angle $(2 \theta)$ of natural bentonite, bentonite with heating at $400^{\circ} \mathrm{C}$ and bentonite with acidification using sulfuric acid ie the shifting angle of motnmorillonite diffraction at $4.1^{\circ}, 3.3^{\circ}$ and $4.1^{\circ}$.

The existence of diffraction at the $2 \theta$ angle of $20^{\circ}$ and $26^{\circ}$ as shown in Figure 4 (A), (B), and (C) indicates the existence of 
other minerals ie quartz and illite. If bentonite is intercalated by molecules and compounds, there will be XRD diffraction patterns shift of montmorillonite, quartz, and illite (Bertella et al,. 2011 ). In Figure 4 (D) shows the weight ratio (1: 1), there is a shift in the diffraction angle of $2 \theta$ montmoriloite in bentonite of $5.2^{\circ}$ with basal spacing of $16.7 \AA$.

In comparison (1:2) presented in Figure 4 (E) also seen shift angle diffraction $2 \theta$ montmoriloit at $5.3^{\circ}$ with basal spacing 16.4 Á. In Figure $4(\mathrm{~F})$, the ratio (1:3) also shows a shift in the angle of diffraction of $2 \theta$ montmoriloite at bentonite of $5.2^{\circ}$ with basal spasing of $16.8 \AA$. The shift of the diffraction angle $2 \theta$ in the ratio of the weight of bentonite to the organometallic compound $\left[\mathrm{Fe}_{3} \mathrm{O}\left(\mathrm{OOCC}_{6} \mathrm{H}_{5}\right)_{6}\left(\mathrm{H}_{2} \mathrm{O}\right)_{3}\right]\left(\mathrm{NO}_{3}\right) \cdot \mathrm{nH}_{2} \mathrm{O}$ can be seen in Figure 4 (D), (E), (F), and (G).

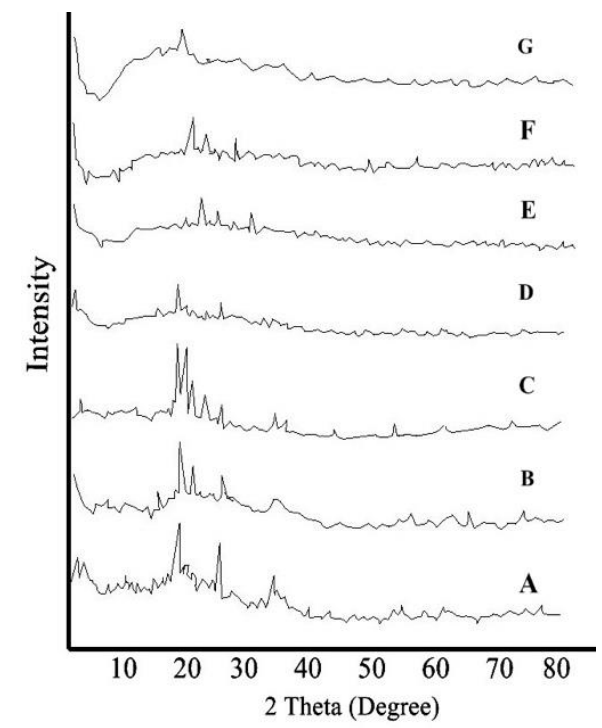

Figure 4 Diffraction patterns of A) natural bentonite, B)

bentonite with heating at $400{ }^{\circ} \mathrm{C}$ C) bentonite with acidification D) bentonit:organometallic 1:1, E) 1:2, F) 1:3, and G) 1:4.

In the ratio (1: 4) shown in Figure $4(G)$ it does not have a $2 \theta$ montmorillonite diffraction angle shift in bentonite but has a basal spacing of $24 \AA$. This can not be said to be optimal because there is no shift in the diffraction angles of $2 \theta$ montmorillonite. The success of bentonite intercalation of organometallic compounds can be seen from the shifting angle of diffraction of $2 \theta$ montmorillonite from $3-6^{\circ}$. In Figure $4(\mathrm{G})$ the entry of organometallic compound is not only in 1 layer, but in other layers as well.

Therefore, the results of the XRD characterization data can be stated that in the weight ratio of bentonite: organometallic compound (1:3) is more optimally intercalated. To be able to demonstrate the optimal intercalation results, another process of characterization was conducted using XRF analysis (X-ray Fluorescence).

\section{Identification of Natural Bentonite and Bentonite Intercalated Organometallic Compounds $\left[\mathrm{Fe}_{3} \mathrm{O}\left(\mathrm{OOCC}_{6} \mathrm{H}_{5}\right)_{6}\left(\mathrm{H}_{2} \mathrm{O}\right)_{3}\right]\left(\mathrm{NO}_{3}\right) \cdot \mathrm{nH}_{2} \mathrm{O}$ using X-Ray Fluorescence Sinar-X (XRF)}

Characterization using XRF aims to look at the metal oxide compositions contained in natural bentonite, activated bentonite and intercalated bentonite with organometallic compound in the ratio (1: 1), (1:2), (1: 3 ) and (1: 4$)$. The results data of XRF analysis is presented in Table 3 . In Table 3 it is seen that natural bentonite is composed of montmorillonite mineral containing silica and alumina which yield percentage amount of $\mathrm{Al}_{2} \mathrm{O}_{3}$ and $\mathrm{SiO}_{2}$ metal oxides of $17 \%$ and $43.6 \%$. Other measured metal oxides are $\mathrm{P}_{2} \mathrm{O}_{5}$ with a percentage of $0.71 \%, \mathrm{~K}_{2} \mathrm{O}$ with a percentage of $0.2 \%$. Composition of $\mathrm{CaO}$ with percentage as much as $0.99 \%, \mathrm{TiO}_{2}$ with percentage $1.87 \%, \mathrm{~V}_{2} \mathrm{O}_{5}$ with percentage $0.11 \%, \mathrm{Cr}_{2} \mathrm{O}_{3}$ with percentage $33.39 \%$, NiO with percentage $0.87 \%, \mathrm{CuO}$ with percentage $0.15 \% \mathrm{ZnO}$ with a percentage of $0.09 \%, \mathrm{Re}_{2} \mathrm{O}_{7}$ with $0.11 \%$ percentage, and $\mathrm{Eu}_{2} \mathrm{O}_{3}$ with $0.2 \%$.

With the activation of natural bentonite causes the value of metal oxide content decreases. This is in accordance with the activation purpose of removing impurities on bentonite in the form of small metals. Activation of the first bentonite by heating at $400^{\circ} \mathrm{C}$ indicates that some oxides are decreased, as $\mathrm{CaO}$ decreases its percentage to $0.92 \%, \mathrm{~V}_{2} \mathrm{O}_{5}$ to $0.07 \%$. While other metal oxides have the same percentage as natural bentonite despite the presence of binding metal oxides, such as $\mathrm{TiO}_{2}$ to $1.91 \%, \mathrm{Cr}_{2} \mathrm{O}_{3}$ to $0.11 \%, \mathrm{Mn}$ to $0.19 \%, \mathrm{Fe}_{2} \mathrm{O}_{3}$ to $33.57 \%$. This reduction in metal oxide content due to metal oxides on the bentonite is already lost oxide activation due to heating to form other inorganic substances.

Tabel 2.Metal oxide composition using XRF

\begin{tabular}{|c|c|c|c|c|c|c|c|c|c|c|c|}
\hline Samper & $\begin{array}{c}\mathrm{Al}_{2} \mathrm{O}_{3} \\
(9 \%)\end{array}$ & $\begin{array}{l}\mathrm{SiO}_{2} \\
(96)\end{array}$ & $\begin{array}{c}\mathrm{Fe}_{2} \mathrm{O}_{3} \\
(\%)\end{array}$ & $\begin{array}{c}\mathrm{P}_{2} \mathrm{O}_{3} \\
(\%)\end{array}$ & $\begin{array}{l}\mathrm{K}_{2} \\
{ }_{2}\end{array}$ & & 90 & $\begin{array}{l}\mathrm{TiO}_{2} \\
(\%)\end{array}$ & $\begin{array}{c}\mathrm{V}_{2} \mathrm{O}_{3} \\
(\%)\end{array}$ & $\begin{array}{c}\mathrm{C}_{2_{2} \mathrm{O}_{3}} \\
(96)\end{array}$ & $\begin{array}{l}A \mathrm{~S} 0 \mathrm{O} \\
(\%)\end{array}$ \\
\hline BA0 & 17 & 43,6 & 33,57 & 0,71 & 0,2 & & 997 & 1,87 & 0,11 & 0,075 & 0,12 \\
\hline B 400 & 17 & 43,7 & 33,57 & 0,7 & 0,2 & & 92 & 1,91 & 0,074 & 0,11 & 0,19 \\
\hline BAA & 11 & 28,8 & 29,2 & - & 0,1 & & 94 & 1,73 & 0,062 & 0,068 & 0,17 \\
\hline HAl & 10 & 29,7 & 55,22 & 0,67 & - & & 67 & 1,41 & 0,063 & 0,088 & 0,13 \\
\hline $\mathrm{HB} 2$ & 8,2 & 23,9 & 63,89 & 0,43 & $0,1 \mathrm{C}$ & & 57 & 1,06 & 0,03 & 0,095 & 0,11 \\
\hline HC3 & 6,2 & 18,7 & 71,75 & 0,42 & 0,08 & & 084 & 0,815 & 0,03 & 0,100 & 0,089 \\
\hline HD4 & 6,1 & 19 & 70,12 & 0,45 & 0,08 & & 35 & 0,67 & 0,02 & 0,11 & 0,080 \\
\hline Sacpel & $\begin{array}{l}\text { Dia. } \\
(\%)\end{array}$ & $\begin{array}{l}\mathrm{g} \mu \mathrm{Q} \\
(\%)\end{array}$ & $\begin{array}{l}\mathrm{P}, \mathrm{O}_{t} \\
(\%)\end{array}$ & $\begin{array}{l}7 \mathrm{znO} \\
(\%)\end{array}$ & $\begin{array}{l}\mathrm{R} \mathrm{e}_{\%} \mathrm{O}_{7} \\
(\%)\end{array}$ & $\begin{array}{l}\mathrm{Rb}, 0 \\
(\%)\end{array}$ & $\begin{array}{l}\mathrm{SO}_{3} \\
(\%)\end{array}$ & $\begin{array}{l}\mathrm{MoO} ; \\
(\%)\end{array}$ & $\begin{array}{c}\mathrm{Eu}_{2} \mathrm{O}_{2} \\
(\%)\end{array}$ & $\begin{array}{l}\mathrm{Re}_{0} \mathrm{O}_{7} \\
(\%)\end{array}$ & $\begin{array}{l}\mathrm{NiQ} \\
(\%)\end{array}$ \\
\hline $\mathrm{BA}$ & 0,899 & 0,1 & 0,71 & 0, & & 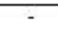 & & - & 0,2 & & 0,899 \\
\hline B40 & 0,899 & 0, & 0,7 & 0,08 & 0,1 & - & - & - & - & 0,1 & 0,899 \\
\hline BAA & 0,882 & 0,15 & - & 0,080 & 0,1 & - & 17 & 9,6 & - & 0,1 & 0,882 \\
\hline HA & 1,03 & 0 , & 0,8 & - & - & - & - & - & - & & 1,03 \\
\hline HB? & 0,945 & 0 & & - & - & 0,3 & - & - & - & - & 0,945 \\
\hline $\mathrm{HC} 3$ & 0 , & 0 , & 0,42 & - & - & 0,36 & - & - & - & - & 0,93 \\
\hline HD4 & 0,82 & 0,13 & 0,45 & - & - & 0,37 & - & - & - & - & 0,82 \\
\hline
\end{tabular}

BAO: natural bentonite; B400: physical activation at $400{ }^{\circ} \mathrm{C}$; BAA: chemical activation using sulfuric acid; HA1: (1:1); HB2: (1:2); HC3: (1:3); HD4: (1:4).

The second activation of natural bentonite by adding sulfuric acid. This causes a decrease in the percentage of metal oxide. The decrease in the percentage of metal oxide on the acidified bentonite is shown in Table 2 . The decrease of metal oxide is $\mathrm{Al}_{2} \mathrm{O}_{3}$ to $11 \%, \mathrm{SiO}_{2}$ to $28.8 \%, \mathrm{~K}_{2} \mathrm{O}$ to $0.19 \%, \mathrm{TiO}_{2}$ to $1.73 \%$, $\mathrm{V}_{2} \mathrm{O}_{5}$ to $0.06 \%, \mathrm{Cr}_{2} \mathrm{O}_{3}$ becomes $0.06 \%, \mathrm{Mn}$ to $0.17 \%, \mathrm{Fe}_{2} \mathrm{O} 3$ to $29.2 \%$, NiO to $0.88 \%$, and $\mathrm{CuO}$ to $0.15 \%$.

Furthermore, to determine the results of intercalation of bentonite with organometallic compound $\left[\mathrm{Fe}_{3} \mathrm{O}\left(\mathrm{OOCC}_{6} \mathrm{H}_{5}\right)_{6}\left(\mathrm{H}_{2} \mathrm{O}\right)_{3}\right]\left(\mathrm{NO}_{3}\right) \cdot \mathrm{nH}_{2} \mathrm{O}$ in the ratio (1: 1), (1: 2), (1:3) and (1:4) are performed by observing the oxide content, especially the $\mathrm{Al}_{2} \mathrm{O}_{3}$ and $\mathrm{SiO}_{2}$ metal oxides located on the inseminating montmorillonite layer. Then the intercalation compound content of organometallic compound causes the metal oxide of $\mathrm{Fe}_{2} \mathrm{O}_{3}$ to increase. The result of XRF analysis in Table 2 shows that the ratio of weight (1:2) and (1: 3) has significant decrease of $\mathrm{Al}_{2} \mathrm{O}_{3}, \mathrm{Al}_{2} \mathrm{O}_{3}$ has a percentage of $8.2 \%$, 
$\mathrm{SiO}_{2}$ has a percentage of $23.9 \%$ and an increase of $\mathrm{Fe}_{2} \mathrm{O}_{3}$ to 63 , $89 \%$.

However, in the weight ratio (1:3) the metal oxide decreased $\mathrm{Al}_{2} \mathrm{O}_{3}$ to $6.2 \%, \mathrm{SiO}_{2}$ had a percentage of $18.7 \%$ and the increase of $\mathrm{Fe}_{2} \mathrm{O}_{3}$ to $71.75 \%$. Therefore, the result of bentonite intercalation of the optimal organometallic compound is shown in the ratio (1:3) because it contains a lot of $\mathrm{Fe}_{2} \mathrm{O}_{3}$ composition as well as decreasing the good percentage of each treatment.

\section{CONCLUSION}

Bentonite intercalated organometallic compounds $\left[\mathrm{Fe}_{3} \mathrm{O}\left(\mathrm{OOCC}_{6} \mathrm{H}_{5}\right)_{6}\left(\mathrm{H}_{2} \mathrm{O}\right)_{3}\right]\left(\mathrm{NO}_{3}\right)$ showed optimal intercalation process in the weight ratio (1:3). Characterization using XRD showed an diffraction at $5.2^{\circ}$ having a basal spacing of $16.8 \AA$. Further characterization using XRF showed the intercalation (1: 3) has percentage $12.75 \%$ of metal oxide.

\section{ACKNOWLEDGEMENT}

We thank to Prof. Aldes Lesbani for fruitful disscusion related with this research. HPU and DMS thanks to Integrated Research Laboratory, Graduate School, Sriwijaya University for laboratory equipment and support.

\section{REFERENCES}

Abderrazek, K., Najoua, F.S. and Srasra, E., 2016. Synthesis and characterization of [ $\mathrm{Zn}-\mathrm{Al}] \mathrm{LDH}$ : Study of the effect of calcination on the photocatalytic activity. Applied Clay Science, 119, 229-235.

Bertella, F. and Pergher, S.B.C., 2015. Pillaring of bentonite clay with $\mathrm{Al}$ and Co. Microporous and Mesoporous Materials, 2011, 116-123

Brindley, W., and Brown, G. (1980). Crystal Structure of Clay Minerals and their X Ray Identification, Mineralogical Society, London.

Derrick, M, R., Szubik, D, and Landry, J M., 1999. Infrared Spectroscopy Conservation Science. The Getty Conservation Institue. Los Angeles.

Ding, M., Zuo, S. and Qi, C., 2015. Preparation and characterization of novel composite AlCr-pillared clays and preliminary investigation for benzene adsorption. Applied Clay Science, 115, 9-16.

Gil, A., Assis, F.C.C., Albeniz, S., and Korili, S.A., 2011. Removal of dyes from wastewaters by adsorption on pillared clays. Chemical Engineering Journal, 168(3), 1032-1040.

Hasegawa, T., Fernanda F. M., David J. E, S., and Nunes., 2007. A new capped iron(III) trinuclear benzoate cluster. Journal of Coordination Chemistry. 60(2), 185-191.

Lesbani, A., Kawamoto, R., Uchida, S., and Mizuno, N., 2008. Control of structures and sorption properties of ionic crystals of $\mathrm{A}_{2}\left[\mathrm{Cr}_{3} \mathrm{O}\left(\mathrm{OOCC}_{2} \mathrm{H}_{5}\right)_{6}\left(\mathrm{H}_{2} \mathrm{O}\right)_{3}\right]_{2}\left[\alpha-\mathrm{SiW}_{12} \mathrm{O}_{40}\right](\mathrm{A}=$ $\left.\mathrm{Na}, \mathrm{K}, \mathrm{Rb}, \mathrm{NH}_{4}, \mathrm{Cs}, \mathrm{TMA}\right)$. Inorganic chemistry, 47(8), 334957.

Ozcan, A., Omeroglu, C., Erdogan, Y., and Ozcan, A, S. 2007. Modification of Bentonite with A Cationic Surfactant; An Adsorptio Study of Textile Dye Reactive Blue 19. Journal of Hazardous. 140; 173-179.

Ozcan, S, A., and Ozcan, A. 2004. Adsorption of Acid Dyes from Aqueos Solutions onto Acid-Activated Bentonite. Journal of Colloid and Interface Science. 276: 39-46.

Santos, S.C.R., Oliveira, Á.F.M. and Boaventura, R.A.R., 2016. Bentonitic clay as adsorbent for the decolourisation of dyehouse effluents. Journal of Cleaner Production, 126, 667-676.

Scoonheydt, R.A., Pinnavaaia, T.,Lagaly, G., and Ganga, N.1999. Pillared Clays and Pillared Layered Solids. Belgium.

Szafran, Z., Pike, R.M., Singh, M.M. 1991. Microscale Inorganic Chemistry: A Comprehensive Laboratory Experience, Wiley.

Uchida, S., Lesbani, A., Ogasawara, Y., and Mizuno, N., 2012. Ionic Crystals $\left[\mathrm{M}_{3} \mathrm{O}\left(\mathrm{OOCC}_{6} \mathrm{H}_{5}\right) 6\left(\mathrm{H}_{2} \mathrm{O}\right)_{3}\right]_{4}\left[\alpha-\mathrm{SiW}_{12} \mathrm{O}_{40}\right](\mathrm{M}$ $=\mathrm{Cr}, \mathrm{Fe})$ as Heterogeneous Catalysts for Pinacol Rearrangement. Inorganic Chemistry, 51(2), 775-777.

Yang, R.T., 1999, Structual Aspects of Metal Oxide Pillared Sheet Silicates, J. Chem. Soc. Faraday Trans

Zhu, H.,M and Vansant,.E.E., 2008. Corelation Beetween The Micropore Structure and The Adsorption of Benzone in Plillared Clays, Separtion Technology. Amsterdam. 466: 153158. 